\title{
1977 BIRD OBSERVATIONS IN THE CARIBOU MOUNTAINS, ALBERTA
}

E. OTTO HOHN, Dept. of Physiology, University of Alberta, Edmonton, T6G 2H7 and D. V. WESELOH, Dept. of Ornithology, Royal Ontario Museum, Toronto.

In continuation of field work previously reported in the Blue Jay $(1975,33: 73-86,1976,34: 56-58$ and 116117) we visited Rock Island Lake July 23 to 26 and Margaret Lake July 26 to 29, 1977. Our main objective was to find evidence of breeding for Graycheeked Thrushes and Northern Phalaropes. However, our visit was evidently too late in the season, for no phalaropes or thrushes, not even robins, were seen.

Our findings in regard to Redthroated Loons were also disappointing. We found no loons on the two small lakes which had a nest each in 1976. On the other hand, several sightings of these loons fishing in Rock Island Lake and flying off carrying a fish, presumably to smaller breeding lakes, indicated that there had been some successful nesting. Five Redthroated Loons were seen in a group at the east end of Margaret Lake and two apparent pairs were seen on two small lakes near the west end of this lake, an area not previously visited by our parties.

Circumstantial but not conclusive evidence of breeding of Mew Gulls not yet found nesting in Alberta, was obtained at a small lake near Margaret Lake. Here two pairs of these gulls had dived at us with much calling in late June, 1976, suggesting they were breeding although no nest with young could be found. This year we found a young Mew Cull, already able to fly, on July 26 at the same place.

When Weseloh revisited the lake that evening there was also an adult which dived and screamed at him, but did not associate with the juvenile.

In earlier reports on this area the possibility that Greater Scaup may nest there was raised but a downy duckling collected on Margaret Lake in late June, 1976, was identified by $W$. E. Godfrey as a Lesser Scaup, and a female with a brood, taken on a small lake near there on July 27, 1977, also proved to be of this species.

\section{BIRDS NOT PREVIOUSLY}

RECORDED IN THE AREA

SHARP-SHINNED HAWK: one was seen in flight and perched at a small lake near Rock Island Lake on July 24.

SEMI-PALMATED PLOVER: one shared a strip of sandy beach on Rock Island Lake with three Least Sandpipers for a few hours on July 24.

SHORT-EARED OWL: no owls had previously been observed, although feathers of the Great Horned Owl were found in two years (and were again found this year). On July 27 we saw a Short-eared Owl flying over a small lake near Margaret lake where it was at times mobbed by a Common Tern.

HAWK OWL: on the morning of July 26 a Hawk Owl flew about 20 feet above the ground over our campsite on Rock Island Lake and then perched on a spruce about 150 yards away for a brief period

DOWNY WOODPECKER: the only woodpecker previously recorded was the Common Flicker but on the evening of July 25 a Downy was seen on the shore of Rock Island Lake.

NORTHERN THREE-TOED WOODPECKER: a male was collected near Margaret Lake on July 27.

RED-BREASTED NUTHATCH: As we were leaving the Fishing Lodge on Margaret Lake on July 23 one of us heard the unmistakable calls of one of this species. 